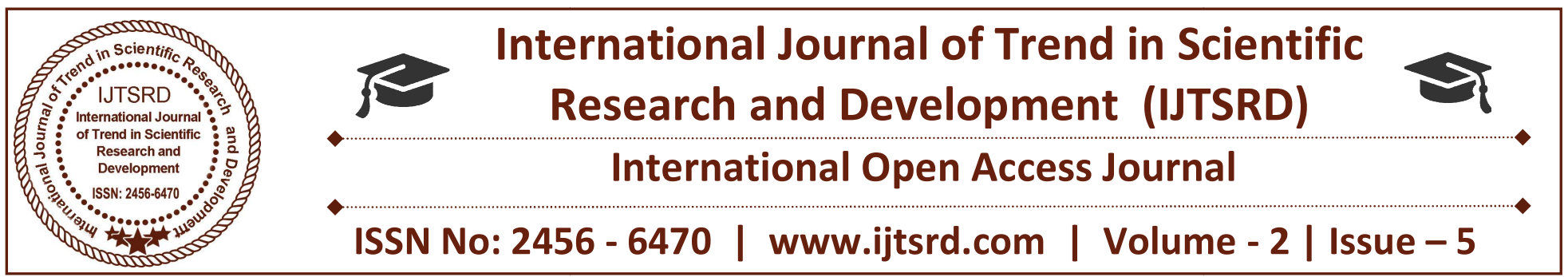

\title{
Repositioning Reading Comprehension for Learner Autonomy in English as a Second Language
}

\author{
Clement Gowon Omachonu PhD, Sunday Sule Emah PhD \\ Department of Arts Education, \\ Kogi State University, Anyigba, Nigeria
}

\begin{abstract}
The ultimate aim of any reading effort is to first and foremost comprehend the message of the text being read. It is only when one comprehends that one enjoys a given text and one is expected to react, evaluate and benefit from the reading exercise. Reading, whether in the first or second language context, involves the reader and the text. Although reading in the L1 shares numerous important basic elements with reading in the L2, the processes differ. This paper focuses on the challenges English Language learners face in achieving autonomy in reading comprehension. The paper also offers suggestions for teachers of English as a second language to enable them achieve better service delivery. One of such suggestions is that teachers of L2 readers should create time to build their learners' background knowledge to enable them create mental schema for text organization. This will help them to achieve autonomy in reading.
\end{abstract}

Keywords: Reading Comprehension, Learner Autnomy, English, Second Language

\section{INTRODUCTION}

Reading is a domain of language proficiency that encompasses how a reader processes, interprets and evaluates written language, symbols and texts with understanding and fluency. It is a process of retrieving and comprehending some form of stored information or ideas in written form. The goal of reading is to construct text meaning based on visually encoded information (Koda, 2007). In first language (L1) reading, readers use only one language, whereas in second language (L2) reading, leaners have at least two languages to contend with. Carrel and Grabe

(2002) noted that L2 readers are limited in their linguistic knowledge as a result of the following:

> They do not have cultural and social knowledge that is common in the English context;

> They do not necessarily retain prior knowledge , which is the basis for understanding English material;

They study English for a variety of reasons;

They use both $\mathrm{L} 1$ and $\mathrm{L} 2$ during reading exercises

These differences have made reading in the English Language more challenging for the L2 readers thereby preventing them from achieving learning autonomy. This paper aims at presenting the challenging issues leaners of English as a second language face in reading in the English Language and to suggest ways for teachers of English as a second language for better instruction that could lead to learning autonomy.

\section{Learner Autonomy}

Learner autonomy is the power of learners to make their own decisions with regard to learning. It is a situation whereby learners themselves participate in deciding the content of their learning and how to go about it. Its principle is to make the learner part of the learning process. According to Little (2000), learner autonomy involves teacher guidance, individual work, pair work, use of projects, brief plenary sessions conducted by the teacher at the beginning and end of lesson. It emphasizes the ability of learners to develop the capacity for independent thought and critical reflection, of helping them to learn how to learn. 
Learner autonomy calls for the need to bring up learners who can approach learning in an independent, active, purposeful and deliberate manner. Efficient learners are known to be independent in their learning orientation. They are usually characterized by their active involvement and efficient management of learning experiences. To achieve learner autonomy in reading comprehension, therefore, would mean the ability of learners of English as a second language to read and comprehend independently of the teacher or, at best, the teacher serves as a guide to the learner in his reading comprehension activity.

\section{Reading Comprehension}

Reading is the ability to interpret the written words and to gain meaning from them. It is the decoding of information presented in writing. It involves making visual contact with the letters of the alphabet and relating them to the sounds of the language which they represent. Ogwu (1999) sees reading as the meaningful interpretation of written symbols; a complex process that involves the physical, mental, and emotional abilities and conditions of the readers and the kind of material to be read. To read efficiently, a reader must be able to perceive the individual letters of the alphabet, their arrangement into words, and the arrangement of words into groups to form sentences. This implies that reading is not a mechanical response to symbols but a process whereby symbols are interpreted and placed within the wider structure of language. The words 'language', 'symbol' and 'interpret' are significant to our conception of reading. This is because when oral language is reduced to written form, it becomes coded in mute symbols which must be interpreted (by the reader) to elicit the message. Reading, therefore, involves an understanding or comprehension, not only of the literal sense of the meaning of printed material, but also of the meaning implied by the author, his mood, tone, intent and even his attitude towards his readers and himself (Unoh, 1989).

Comprehension is the process of understanding the ideas expressed in the written or printed text. To understand the ideas, the reader and the texts interact. In other words, during the reading comprehension process, the reader is actively trying to make sense of the written texts by integrating his previous relevant experiences with text information. Dawson and Bamman (1980) point out that the purpose of reading is not simply emitting sounds and naming words but rather for comprehension. This presupposes that reading without comprehension is a meaningless exercise. Comprehension is an essential part of the reading process where the reader understands not only the meaning of isolated words, but also their meanings when combined in phrases, sentences and longer strings. A reader's previous knowledge or experience is very important for comprehension. Reading comprehension is based on using the appropriate meaning-making processes from the printed messages. It involves the passage, the reader and the context. Readers construct meanings with various approaches, such as using background knowledge, analyzing words, inferring the text, and identifying key vocabulary or information.

The importance of reading for comprehension has been greatly emphasized by educationists and psychologists as the child's progress in school hinges on the ability to read and comprehend presented materials. Crain-Thoreson, Lppman and MccledonMagnuson (1997) point out that there is a positive correlation between reading comprehension and school success. According to Omachonu and Offorma (2008), learning depends on the comprehension and retention of new information. This means that a lot of emphasis must be placed on reading comprehension in school in other to overcome the challenges learners of English Language as a second language face in achieving learning autonomy in the English Language.

\section{Challenges of Second Language Readers}

Learners of English as a second language face some challenges in the process of reading which could prevent them from achieving learning autonomy. Some of these challenges include: culturally different schemata, lack of vocabulary knowledge and translation from L1 to L2. These are dealt with below:

\section{Culturally Different Schemata}

Schemata have been described as cognitive constructs which allow for the organization of information in the long term memory. It consists of generalized information abstracted from a variety of instances and show the relationships among their component elements. In addition to allowing readers to organize information and knowledge economically, schemas allow readers to predict the continuation of both spoken and written discourse. The first part of a text activates a schema, that is, calls up a schema which is either confirmed or disconfirmed by what follows. The mind stimulated by key words or phrases in the 
text or by the context, activates knowledge schema. Windowson (1983) and Cook (1989) both emphasize the cognitive characteristics of schema which allows readers to relate the incoming information to already known information. Rich schemata, therefore, can help readers understand the reading material better than readers without background information on the topic.

Cultural orientation in terms of background knowledge is a factor that influences L2 reading. Although all the variables and factors surrounding the issues of how culture shapes background knowledge and influences reading are not fully understood, there is agreement that background knowledge is important and that content schema plays an integral role in reading comprehension (Singhal, 1998). Readers appear to have a higher level of comprehension when the content is related to their cultural background. Given this, L2 readers do not possess the same degree of content schema as $\mathrm{L} 1$ readers, and hence, this can result in comprehension difficulties. Singhal (1989) points out that the L2 readers who do not possess cultural background knowledge on an English text are limited in comprehending the text's message. This could hinder learner autonomy in reading comprehension. It is therefore important to recognize that organizational structure in text differ across cultures, hence the challenge of culturally different schemata.

\section{Lack of Vocabulary Knowledge}

Studies have shown that the knowledge of letter names is a good indicator of success in learning to read. A student who has learnt to associate a name with a letter has already learnt a basic reading skill. He has learnt how to discriminate one visual form from another and has associated a sound and consequently a name and meaning with that symbol. The reason for this is that the traditional theory of reading portrays reading as a bottom-up process. According to this theory, the processing begins with letter features which give rise to letter recognition, which in turn leads to word recognition. Words are then recorded to inner speech, from which the reader derives meaning. Comprehension is an automatic outcome of accurate word recognition. In order to recognize words fast and achieve maximum comprehension, a reader must have acquired a large stock of vocabulary.
Vocabulary is very closely linked to comprehension. Harris and Hodges (1981) recognized the value of vocabulary as a very significant determinant of reading comprehension when they outlined three types of vocabulary:

General vocabulary - number of words which individuals own, add to, and uses in everyday activities;

$>$ Technical terms - used in specialized field of human endeavor; and

$>$ Specialized vocabulary - words which have common and known meanings but which have very different and specific definitions when used in context of a given content area.

The size of one's vocabulary and how accurately one's idea is of what words mean, therefore, are very important factors in understanding what one reads. This is why Hudson (2007) observes that having rich vocabulary knowledge is a key element to better reading comprehension. Insufficient English vocabulary knowledge is a serious challenge to L2 readers in English. L2 readers need to develop their capacity in depth. Some words in the English Language may have more than one meaning and could confuse L2 readers because they do not consider the meaning of the word in the contexts. The word 'freedom', for instance, could have many meanings depending on the context of use. Let us examine the following sentences:

1. "Freedom: the state of being free.

The master gave the slave his freedom.

During the holidays, the children enjoyed their freedom.

2. Freedom: certain rights often given as an honour. They gave her the freedom of their house (gave her the right to use the house as if it were her own).

The minister was given the freedom of the city as an honour (was given certain rights within the city as an honour).

3. Freedom: the power to do, say, think or write as one pleases.

Two of the four freedoms spoken of by President Roosevelt in 1941 are freedom of speech and freedom of religion.

4. Freedom: do what you think best.

You are given the freedom of dealing with this matter. 
Other uses of freedom include: Tight clothes do not allow enough freedom of movement; for the first two days after he broke his arm, he had little freedom from pain.

Learners of English as a second language, therefore, need to develop their vocabulary in depth to understand each meaning of English words in the different contexts to enable them achieve autonomy in reading comprehension.

\section{Translation from $\mathrm{L} 1$ to $\mathrm{L} 2$}

As soon as a child gains fluency in his L1, he begins to express his thoughts or ideas in that language. He is therefore said to be thinking in that language. Therefore, at the early or intermediate stages of learning English as a second language the L2 reader tends to read in English and then translate it into his L1 for comprehension to take place because he has a different constructive process from his L1 experiences. Littlewood (1984) observes that the L2 learner uses his previous L1 experience as a means of organizing the L2 data. This is because the language faculty has been taken over by the features of the L1 with a resulting loss of flexibility or openness to receive another language.

In general, L2 readers, especially in their introductory stage, are likely to translate words from English to their L1. They feel that they are unable to understand what a text is about without understanding the meaning of each word (Singhal, 1998). They stop at a point when they encounter an unknown word to look it up in the dictionary. The danger is that, by the time they translate all unfamiliar words into their L1, they may not retain information from the text and comprehension would not take place.

\section{Suggestions for Teachers of L2 Readers}

The ability to read and read successfully implies text comprehension. Comprehension relies on the mastery of decoding. Since efficient comprehension relies on reader's ability to see the pattern or the direction that the writer is taking, teachers can help the L2 readers by spending more time on building background for the reading selection, both in the general sense of concept building and in specific sense of creating a mental schema for the text organization. One effective strategy for L2 readers is to generate visual images of what is being read (Carnine and Kinder, 1985). For the reader to generate images, he must first be able to recognize words. Assuming the reader knows how to recognize words, he needs concepts to visualize the flow of action presented on the page. The same kind of concept building technique that works for the L1 readers also work for the L2 readers. The L2 readers, however, gain more from concrete experiences and images than from abstract ones (Singhal, 1998). It is not enough for the teacher to simply tell the L2 reader to use visual images, the teacher has to describe the images that occur in his own mind as he reads a particular passage, thus giving the L2 reader a concrete sense of what visual imagery means. Pictures, physical action, demonstrations, practice using words in an exchange of views among peers are some of the ways a teacher can make the key vocabulary items take root in the L2 readers' mind.

In texts where vocabulary is not familiar, teachers can introduce key vocabulary in pre-reading activities that focus on language awareness, such as finding synonyms, antonyms, derivatives, or associated words. Bos (1982) points out that brief plenary sessions by the teacher in the comprehension process increases reading comprehension for L2 readers. These readers often need help with vocabulary and need reminders to summarize as they proceed to enable them achieve autonomy in reading.

It is also necessary for the L2 readers to become aware of the purpose and goal for reading certain material. At the beginning stages, this can be done by the teacher, but as the $\mathrm{L} 2$ reader becomes mature, this purpose, i.e. awareness raising strategy, can be left to the reader. For instance, the reader may be guided to ask himself, "Why am I reading this text? What do I want to know or do after reading?" According to Vaezi (2006), one of the most obvious, but unnoticed, point related to reading purpose is the consideration of the different types of reading skills:

\section{$>$ Skimming - reading rapidly for the main points \\ $>$ Scanning - reading rapidly to find a specific piece of information \\ $>$ Extensive reading - reading a longer text, often for pleasure with emphasis on overall meaning \\ $>$ Intensive reading - reading a short text for detailed information.}

The teacher must, therefore, guide the L2 readers to become familiar with the fact that texts may take different forms and hold certain pieces of information in different places; and that it is necessary to understand the layout of the material being read in 
order to focus more deeply on the parts that are more densely compacted with information.

Furthermore, learners of English as a second language should not be labeled based on their status or cultural background, but rather teachers should respect their individual differences (Nieto, 2003). Since the L2 reader is not equipped with the knowledge to perceive texts in a culturally authentic and culturally specific way, he should be provided with a safe learning environment as comprehension would be only based on linguistic data.

\section{Conclusion}

This paper has discussed the challenging issues learners of English as a second language face in reading comprehension. Factors such as culturally different schemata, lack of vocabulary knowledge and the problem of translation from L1 to L2 were considered. Suggestions were also put forward to the teachers of L2 readers to help learners achieve learning autonomy in reading comprehension in the English language.

\section{REFERENCES}

1. Bos, C. S. (1982). Getting past decoding: assisted and repeated readings as remedial methods for teaching disabled students. Journal of Learning and Learning Disabilities 1 (5) 52 - 57.

2. Carrell, P. L. \& Grab, W. (2002). Reading. In Schmitt, N. (ed.). An Introduction to Applied Linguistics. London: Arnold.

3. Carnine D. \& Kinder, D. (1985). Teaching low performing students to apply generative and schema strategies to narrative and expository materials. Journal of Remedial and Special Education, 6 (1) $20-30$.

4. Cook, G. (1989). Discourse in Language Teaching: a Scheme for Teacher Education. Oxford: Oxford University Press.

5. Crain-Thoreson, C.; Lippman, M. Z. \& Mcclendon-Magnuson, D. (1997). Windows on comprehension processes as revealed by two think aloud procedures. Journal of Educational Psychology, 89 (4) 579 - 591.

6. Dawson, M. A. \& Bamman, H. A. (1980). Fundamentals of Basic Reading Instruction. London: Longman Group Ltd.
7. Harris, T. L. \& Hodges, R. E. (1981). A Dictionary of Reading. Newark, Delaware: International Reading Association.

8. Hudson, T. (2007). Teaching Second Language Reading. Oxford: Oxford University Press.

9. Koda, K. (2007). Reading and language learning: cross linguistic constraints on second language development. Language Learning 57 (1) 1 - 44.

10. Littlewood, D. (2000). Learner autonomy: why foreign languages should occupy a central role in curriculum. In Green, S. (ed). New Perspective on Teaching Foreign Languages. Clevedon: Multilingual Matters Ltd.

11. Nieto, S. (2000). Affirming Diversity: the Sociopolitical Context of Multicultural Education. $\left(3^{\text {rd }}\right.$ ed.). New York: Longman.

12. Ogwu, O. M. (1999). Reading disability among school children in Nigeria: causes and remedial strategies. Teacher Education Journal, 1 (6) 87 93.

13. Omachonu, C. G. \& Offorma, G. C. (2008). The reading comprehension of junior secondary school students in Idah education zone of kogi state. International Journal of Arts and Technology Education, 7 (1) $160-170$.

14. Singhal, M. (1998). A comparison of L1 and L2 reading: cultural differences and schema. The Internet TESL Journal 4 (10) October. Retrieved on $20-06 \quad-\quad 18$ from http://iteslj.org/Articles/SinghalReadingL1L2.html.

15. Unoh, S. O. (1989). Reading for intellectual development: a psycholinguistic view. In Oyetunde, T. O.; Aliyu, J. S. \& Aboderin, Y. (eds.). Literacy and Reading in Nigeria 5 (2) 14 34.

16. Vaezi, S. (2006). Theories of Reading. Retrieved on $20-06-18$ from

http://www.teachingenglish.org.uk/think/read/rea dingtips.shtml

17. widdowson, H. G. (19983). Learning Purpose and Language Use. Oxford: Oxford University Press. 